\title{
SOME EXAMPLES OF CROATIAN DIALECTS' INFLUENCE ON THE LEXICAL DIVERSITY OF THE CONTEMPORARY LINGUISTIC IDIOM OF ZADAR AMONG NON-NATIVE ELDERLY SPEAKERS
}

\author{
Slavica VRSALJKO*
}

The synchronic linguistic situation of the urban idiom in the city of Zadar is a result of several strands of dialectal influence: Neo-Shtokavian dialect spoken in the hinterland, Chakavian ikavian ("ikavski”) idiom spoken in the coastal region of Croatia, Central Chakavian ikavian-ekavian ("ikavski-ekavski") dialect and standard Croatian. Lisac established that the contemporary Zadar idiom consists of a mixture of two Croatian dialects, Chakavian and Shtokavian, each in turn further subdivided into Central Chakavian and South Chakavian, Bosnian-Herzegovinian and East Herzegovinian, respectively.

Due to varied historical circumstances, within these dialects we find a number of loanwords, mostly Turkish in Shtokavian and Romance borrowings in the Chakavian dialect. To this end the paper uses linguistic contact theory, applied in research on dialects, and explores influence in one direction only: it explores the presence of Turkish loanwords in Croatian idiom of Zadar (in its Shtokavian dialectal component) and Romance loanwords in the Zadar idiom (in its Chakavian component) but not the influence of Croatian on either Turkish or Romance languages. Hence the recipient language is Croatian (here specifically its Zadar idiom) while the donor languages are Turkish and Romance languages, mainly Venetian Italian but also standard Italian, and in some cases we are dealing with linguistic relics of Romance Dalmatian language in Croatian. We have selected to analyse Turkish loanwords in the Shtokavian dialect and Romance loanwords in the Chakavian dialect (within the Zadar idiom) because they are the most frequent foreign borrowings in the Zadar idiom, especially Romance elements that pervade the varieties of Croatian spoken in the coastal region (they often remain on a regional level only but some have passed from Chakavian into Croatian standard).

Keywords: Shtokavian dialect, Chakavian dialect, Croatian history, Turkish loanwords, Romance loanwords

* Slavica Vrsaljko, Ph. D., The Unit for Teacher's Training and Education at the University of Zadar, Zadar, Croatia 


\section{The historical conditions of the dialectological situation in Zadar}

The richness of the Croatian language is manifested, before all else, in its many diverse idioms which serve certain regions either partially or in whole. The language of a nation situated in a certain area is like a living organism that changes, grows and spreads in compliance with historical circumstances and events. ${ }^{1}$ To obtain a clearer picture of the present subject, it is necessary to survey linguistic history of Zadar because a series of historical events have left indelible traces on the linguistic situation. The history of Zadar illuminates the present linguistic diversity of its idiom and more specifically the presence of Turkish and Romance elements within it.

Romance and Slavonic languages first came into contact in the Middle Ages during the $8^{\text {th }}$ and $9^{\text {th }}$ century when the newly-arrived Slavic population encountered Romance-speaking urban dwellers in Dalmatian cities. ${ }^{2}$ Another Romance language came in the form of Venetian in the $14^{\text {th }} / 15^{\text {th }}$ century as Venice captured the coastal cities of Dalmatia including Zadar. Internal strife within the Croatian-Hungarian monarchy, plague, and other diseases took a heavy toll on the rural population so Venice decided to populate rural areas with Slavic migrants coming from elsewhere. As population decline continued in the following centuries Venice favoured a policy of settling Slavic (Dinaric) inhabitants into the cities and islands. The Zadar elite at the time was raised in the mentality of its Italian (Venetian) conqueror and received Italian culture, language and customs. After the Turkish invasion the situation in Zadar changed very frequently.

To understand the linguistic history of Zadar we must turn to the essential studies of Dalibor Brozović, Mate Hraste, and Josip Lisac.

Brozović gives a very detailed overview of the linguistic history of Zadar and its surroundings. ${ }^{3}$ For the present work it is very important to highlight the fact that Latin took a firm hold in this area after the Roman conquest and appeared in two forms, standard and vulgar Latin. The Roman element continued to exist for centuries after the Croats arrived in the form of Dalmatian language. When Croats first settled in the area of present-day Croatia, the dialect spoken in the Zadar area was Chakavian from which two other subdialects later developed. ${ }^{4}$ As we have noted, Hraste says that a great number of Croatians also lived in Zadar in this period and inhabitants in its surroundings alre-

\footnotetext{
Dunja Pavličević-Franić, Komunikacijom do gramatike, (Zagreb: Alfa, 2005),p. 14.

2 For details see Radoslav Katičić Litterarum studia - Književnost i naobrazba ranog hrvatskog srednjovjekovlja, (Zagreb: Theoria, 1998).

3 For greater detail see Dalibor Brozović “O suvremenoj zadarskoj miksoglotiji i o njezinim društveno-povijesnim i lingvističkim pretpostavkama”, Radovi Filozofskog fakulteta u Zadru, (1975-76), 14/15: 51. The author gives an overview of the linguistic history of Zadar and its surroundings in 25 points.

4 Dalibor Brozović, “O suvremenoj zadarskoj miksoglotiji i o njezinim društveno-povijesnim i lingvistčkim pretpostavkama”, Radovi- razdio filoloških znanosti, 9 (1975/1976): 52.
} 
ady spoke Slavonic. ${ }^{5}$ Thus the Chakavian dialect was spoken in all this area in the Middle Ages and the mountain of Dinara formed a natural barrier towards the speakers of Western Shtokavian. Hraste further claims that the first Croats to enter the Venetian city were speakers of Chakavian which was spoken all along the coast around Zadar. At one point the remnants of this state of affairs could still be seen in the linguistic and demographic continuity of a place called Stanovi, which has now been incorporated into the suburbs of Zadar and once used to be two kilometres away from the city. The name of the place signified the pastoral huts of the people of Varoš neighbourhood in the Zadar city centre. Hence the inhabitants who came in the city in the second half of the $15^{\text {th }}$ century were the dwellers of Varoš, a rural population that entered the city and settled in its southern part, a suburban district adjacent to the city walls. This area was their permanent home while they kept their pastoral huts (Stanovi) in the fields north of Zadar. ${ }^{6}$ However, after the Turkish invasion, most of the Varoš population moved over to Stanovi which brought them closer to their fields. Hence, for a long time the population of Stanovi maintained the original Chakavian dialect that had been spoken spoken in the wider area.

At the beginning of the period of great Shtokavian migrations, which were primarily caused by the Turkish invasion, the speakers of two Neo-Shtokavian Shtakavian dialects arrived in the Zadar area. The Venetian administration saw to the growth of the urban population and the presence of the Venetian dialect which soon it met competition in the form of standard Italian (i.e. standard Tuscan) language (in both written and oral communication) which eventually completely replaced the Venetian idiom. Until the end of the $18^{\text {th }}$ century Venetian administration continued to settle Croatians in the city for several reasons. The primary cause was the Turkish invasion in the hinterland of Zadar and the area of Ravni Kotari which triggered great migrations in the whole area, not least due to various diseases. Venice insisted on Croatians entering the cities while it settled the surrounding places with new Slavic populations. Since then, the first preserved censuses of the Croatian population, from Zadar, were recorded (from the year 1527) and the Venetian official reports used this to collect data on the number of inhabitants in Dalmatian towns, and since the middle of the century they acquired their first regional data on the number of inhabitants in Dalmatia. ${ }^{7}$

The dialectal situation in the whole area around Zadar changed significantly after the great migrations in the hinterland while the Chakavian-speaking population moved to the city, places on the coast and the islands. ${ }^{8}$

\footnotetext{
Mate Hraste, O govoru Zadra i okolice, (Zagreb: Nakladni zavod Matice hrvatske, 1964), p. 443.

6 Hraste, O govoru Zadra i okolice, p. 448.

7 Raukar, 1997, according to: Lelija Sočanac, Hrvatsko-talijanski jezični dodiri, (Zagreb: Nakladni zavod Globus, 2004), p. 77.

8 Josip Lisac, Hrvatska dijalektologija 2. (Zagreb: Golden marketing - Tehnička knjiga, 2009), p. 30 .
} 
Nevertheless, all of the literary works created in the 15th and 16th century in the Zadar area, were created in the Chakavian dialect, in the city centers of Zadar, Split and Hvar. ${ }^{9}$

On the other hand, in the $18^{\text {th }}$ century the regional Neo-Shtokavian literacy of the Zadar region became a part of a new idiom in the form of Neo-Shtokavian literary Croatian which began to be standardized at the time while still retaining the duality of both ikavian and ekavian reflexes of Old Church Slavonic è. Zadar had a prominent place in the area where this duality was more conspicuous. In the beginning the ikavian variant was dominant but Croatian standard Neo-Shtokavian received its modern material and linguistic form at the turn of the century.

For the first time Slavic and Romance elements conflicted in the $19^{\text {th }}$ century. However, in the $20^{\text {th }}$ century Zadar was severed from its hinterland because of Italian territorial expansion on eastern Adriatic. After the treaty of Rapallo in 1920 most of the Zadar population was forcefully turned Italian while many Croatian inhabitants moved to the neighbouring cities that were not occupied by the Italians. ${ }^{10}$

The Italian occupation brought a number of varied Italian dialects and interdialects into Zadar which caused the decomposition of both the local Italian Venetian and the customary vernacular speech. Brozović concludes that in time several inorganic vernacular idioms of an interdialectal sort were formed in this area, at least two Chakavian and two Shtokavian idioms. ${ }^{11}$

In his scholarship Lisac frequently stresses the fact that the Zadar region presents an extremely interesting "dialectal landscape". He assumes that the area was first pervaded by non-Slavic idioms and that the first Croats to arrive were speakers of Chakavian which means that Chakavian speakers have been in the area for longest; at first they were not differentiated, but from the $13^{\text {th }}$ century they differentiated into two subdialects, ikavian-ekavian (Central Chakavian) and ikavian (South Chakavian).

The former type is still preserved around Zadar and on the islands from Ugljan to Dugi Otok while the latter is present on the island of Pašman and further south but also on land all the way to Privlaka, and is mixed with Shtokavian along the coast. In the first half of the $16^{\text {th }}$ century Neo-Shtokavian speakers of the ikavian variant arrived in the Zadar region fleeing before the Turkish invasion. At first these are Shtokavian speakers of the ikavian variant from west Herzegovina but soon they are joined by Shtokavian speakers of the ijekavian variant from east Herzegovina. We are dealing here with Chakavian spea-

\footnotetext{
$9 \quad$ Raukar, 1997, according to: Lelija Sočanac, Hrvatsko-talijanski jezični dodiri, p. 94.

10 Zlatko Begonja, “Zadar u sporazumima tijekom prve polovice XX. stoljeća (1915.-1947.)”, Radovi Zavoda za povijesne znanosti HAZU u Zadru, 49 (2007): 510.

11 Brozović, “O suvremenoj zadarskoj miksoglotiji...”, pp. 50-56.
} 
kers leaving their homes and Shtokavian speakers settling in the Zadar hinterland but also to a lesser extent on the islands. The Catholic population coming from west Herzegovina was dominant in Ravni Kotari while the Orthodox population from east Herzegovina prevailed in Bukovica. Along the coast Chakavian and Shtokavian speakers of the ikavian variant were joined by speakers of Shtokavian ijekavian who left the area in the summer of $1995 .^{12}$

After the Second World War, Zadar received a massive influx of new settlers coming from many different areas and bringing a range of dialects that make up the Serbo-Croatian diasystem, but also from other areas of former Yugoslavia, including Slovenia and Macedonia. ${ }^{13}$ In recent studies of Zadar speech Marković (2012) says that Zadar was destroyed and devastated during the Second World War which considerably changed its demographic structure. The Croatian standard, education, media and new language models (along with the prestige they carry) have increasingly come to affect local and individual Croatian forms of speech. According to Marković: ${ }^{14}$

Although a variant of general Dalmatian vernacular continues to appear in phrases (uvatiti tufinu, falija san, etc.), Neo-Shtokavian from the hinterland and standard educational models shape the language of most speakers whose speech is increasingly approaching the standard linguistic model.

Marković also claims that the materials she gathered indicate that local linguistic models have taken hold in this area after the Croatian war of Independence along with variants of Dalmatian vernacular which seeks to reaffirm specific urban and regional identities. However, she concludes that a wider sociolinguistic analysis is necessary to confirm this hypothesis. ${ }^{15}$

Having presented the linguistic history of Zadar we are able to see the reasons for the prominent influence of Turkish on the Shtokavian and Italian on the Chakavian dialect. To discuss specific forms of influence we should start with situations in which specific features of Zadar speech appear. We are dealing with the Zadar variant of the Dalmatian vernacular which stems from the interdialects of the Zadar region. ${ }^{16}$ The contemporary Zadar form of speech is the result of two dialects intermingling (and also various subdialects within the two dialects), i.e. the Zadar vernacular can be the result of a variety of factors: migrations of speakers from the islands, Neo-Shtokavian from the

\footnotetext{
12 Josip Lisac, Hrvatski govori, filolozi, pisci, (Zagreb: Matica hrvatska 1999), p. 74.

13 Hraste, O govoru Zadra i okolice, pp. 443-444.

14 Irena Marković “Jezični utjecaji i promjene u suvremenom govoru Zadra”, Croatica et Slavica Iadertina, (2012): 318.

15 Marković, “Jezični utjecaji i promjene u suvremenom govoru”, p. 318.

16 Lisac, Hrvatski govori, filolozi, pisci, p. 74.
} 
hinterland, Chakavian ikavian from the coastal region and standard Neo-Shtokavian. The Zadar variant of the Dalmatian vernacular or the contemporary speech of Zadar constitutes a linguistically rich and varied material that calls for further analysis. As Brozović states: "It is easy to conclude that the vernacular is quite a homogenous, 'amorphous' inorganic idiom with many pervious channels and the linguistic situation of Zadar offers those channels a truly rich treasury of potentially usable material". ${ }^{17}$ Lisac affirms that speakers of Shtokavian ikavian exert a strong influence on Chakavian speech in the coastal region. ${ }^{18}$ The mixture of these two elements-one native and the other immigrant-is clearly discernible in contemporary speech. One should note that the Shtokavian variety carries more prestige in relation to Chakavian in the same way that urban variety carries prestige in relation to the speech of the hinterland, regardless of its firm Shtokavian basis. ${ }^{19}$

To this end we are using linguistic contact theory, which has been applied in research on dialects, ${ }^{20}$ while exploring influence in one direction only: we discuss the presence of Turkish loanwords in Croatian Zadar idiom (in its Shtokavian dialectal component) and Romance loanwords in the Zadar idiom (in its Chakavian component) but not the influence of Croatian on either Turkish or Romance languages. Hence the recipient language is Croatian (here specifically its Zadar idiom) while the donor languages are Turkish and Romance languages, mainly Venetian Italian but also standard Italian, and in some cases we are dealing with linguistic relics of Romance Dalmatian language in Croatian. We have selected to analyse Turkish loanwords in the Shtokavian dialect and Romance loanwords in the Chakavian dialect (within the Zadar idiom) because they are the most frequent foreign borrowings in the Zadar idiom, especially Romance elements that pervade the varieties of Croatian spoken in the coastal region (they often remain on a regional level only but some have passed from Chakavian into Croatian standard). On the other hand, the situation with Turkish loanwords is different which merits a separate discussion in another part of the paper. As said, the presence of loanwords is a result of historical circumstances and hence the corpus of words used in this paper was collected in informal conversations with elderly inhabitants of Zadar, half of whom are originally speakers of Shtokavian, and half of whom are originally speakers of Chakavian. The initials of the individuals that we interviewed are (with year of birth specified in brackets): J.(B). P. (1925.); K. V. (1930); Š. R. (1930); L. M. (1931); A. D. (1939.); R. D. (1939.), L.M.D. (1948.), S. V. (1948). ${ }^{21}$

\footnotetext{
17 Brozović, "O suvremenoj zadarskoj miksoglotiji i o njezinim društveno-povijesnim i lingvistčkim pretpostavkama”, p. 60.

18 Lisac, “Dijalekti zadarskoga kraja”, p. 521.

19 For greater detail on contemporary Zadar speech see Slavica Vrsaljko, "O suvremenom zadarskom govoru”, Filologija. 64 (2015): 137-145.

20 Spicijarić, "Romanizmi u nazivlju kuhinjskih predmeta u govoru Dubašnice na otoku Krku", p. 8 .

21 To protect the privacy of the interviewees we only give their initials.
} 
The interviewees have lived in Zadar throughout their adulthood (from about 18 years of age) but were not born in Zadar. Half of them came from the region of Ravni Kotari where the Shtokavian dialect predominates and the other half from the islands around Zadar where Chakavian predominates. The corpus has been collected by conversation in informal situations.

The reason we have chosen elderly speakers is the fact that previous studies have shown that young people use on average 10\% fewer Romance loanwords than their elderly counterparts. ${ }^{22}$ Another reason is the aim of this paper, which is to show some examples of lexical diversity stemming from varied forms of dialectal influence and its continued presence among non-native elderly speakers in the city of Zadar.

In fact, previous studies have shown that the Croatian language has a smaller number of borrowed Italian words, which belong to the sphere of cultural lending, for example, some Italianisms from coastal dialects come into subregional use and often remain at a substandard level. ${ }^{23}$

\section{Some examples of dialectal influence on the lexical diversity of Zadar speech}

The literature states how ,there is a tendency to talk about borrowing as if the language is a recipient of a unique entity, which is never the case. That is why many loanwords remain only in dialects and can very rarely enter the standard. On the other hand, loanwords that have entered the standard language will be much easier to expand, even in the dialects. " 24

As said, our overview of the linguistic history of Zadar justifies the focus of this study on Turkish elements in the Shtokavian dialect among native speakers of Shtokavian and Romance elements among native speakers of Chakavian. Namely, it is known that the Croatian language came into contact with the Turkish language during the Turkish invasion of the Balkans, during the 15 th and especially the 16 th century. ${ }^{25}$

We should note that linguistic contact (and influence) between Shtokavian speakers under Venetian rule and Shtokavian speakers under Ottoman rule only took place after Ottoman power took a firm hold in Bosnia and a part of its population (almost forcefully) accepted Islam, and trade relations developed between Venetian and Ottoman territories.

\footnotetext{
22 Marković, “Jezični utjecaji i promjene u suvremenom govoru Zadra”, p. 333.

23 Sočanac, Hrvatsko-talijanski jezični dodiri, p. 103.

24 Ibid., p. 32.

25 Ranko Matasović, Poredbenopovijesna gramatika hrvatskoga jezika, (Zagreb: Matica hrvatska, 2008), p. 311.
} 
In linguistic scholarship along with Turkish loanwords we also find the term "Oriental loanwords," 26 which refers to words coming from Oriental cultures in a wide sense, i.e. "words of Turkish, Arabic and Persian origin and sometimes even other languages such as classical Greek that were transmitted into modern European languages via Turkish" ${ }^{27}$ For this reason we consider as Turkish loanwords in Croatian not only words which have their ultimate source in Turkish but also words of Arabic, Persian, and Greek origin that came into Croatian via Turkish influence (although one can also use the term Oriental loanwords) (http://www.vecernji.hr/hrvatska/svaka-druga-hrvatska-rijec-nije-hrvatska-1080181)

Speakers of Shtokavian undoubtedly adopted a great number of Turkish loanwords which they in turn transmitted to their Chakavian neighbours. ${ }^{28}$ However, in 1975 Brozović ascertained that Turkish loanwords (especially more ancient ones) are less frequent in Zadar speech than elsewhere in Dalmatia and so decided not to analyse this aspect in his diachronic overview. ${ }^{29}$ Lisac says that a great number of so-called Turkish loanwords is present in varieties of Shtokavian, especially in Bosnia and Herzegovina. ${ }^{30}$

Matasović also points out that the number of Turkish words is considerably higher in Shtokavian speaking areas than in Kajkavian and Chakavian, and in the 19th century the Croatian linguists included those words in the standard language with the explanation "that's how the people speak" ${ }^{31}$

In the following table we have noted the loanwords collected during interviews, their meaning within Zadar speech, and their meaning in Turkish. ${ }^{32}$

As said, Turkish loanwords are predominately used by speakers whose speech has been influenced by Shtokavian. All of the examples are attested in Mehmet Işiker's Turkish-Croatian/Croatian-Turkish dictionary ("Tursko-hrvatski/hrvatsko-turski rječnik") and Jure Šonje's Dictionary of Croatian language ("Rječnik hrvatskoga jezika") and they have the same or similar meaning as in the donor language. However, this brief overview seems to confirm Brozović's conclusion on Turkish loanwords being less frequent in Zadar in relation to other areas of Dalmatia.

\footnotetext{
26 Ivo Pranjković, “Hrvatski i orijentalni jezici”, Zbornik Zagrebačke slavističke škole 2001., Jurković M., ed., (Zagreb: Filozofski fakultet, FF press, 2002), pp. 9 - 15.

27 Vladimir Anić et al. Hrvatski enciklopedijski rječnik, I-XII, (Zagreb, Novi Liber, 2004), p. 19.

28 Edo Juraga, “Turcizmi u murterskom govoru”, Čakavska rič, (2010), no. 1-2: 334.

29 Brozović, "O suvremenoj zadarskoj miksoglotiji i o njezinim društveno-povijesnim i lingvistčkim pretpostavkama”, p. 61.

30 Josip Lisac, “Osnovne štokavske značajke i hrvatski standardni jezik”, Republika (LIX), (2003): 89.

31 Matasović, Poredbenopovijesna gramatika hrvatskoga jezika, p. 312.

32 In the table column that specifies word origin and meaning we are using abbreviated forms of citation for convenience.
} 
Table 1.Turkish loanwords

\begin{tabular}{|c|c|c|}
\hline WORD & MEANING IN ZADAR SPEECH & ORIGIN AND MEANING INTURKISH \\
\hline àlaj & ('exclamation') & $\begin{array}{l}\text { Tur. helâl 'the thing or object that is } \\
\text { blessed') (TH/HTR, } 80)\end{array}$ \\
\hline angĩr & 'a naughty, mischevious boy' & $\begin{array}{l}\text { Tur. aygir 'a stud horse, stallion' } \\
\text { (TH/HTR, 25) }\end{array}$ \\
\hline barijãk & $\begin{array}{l}\text { 'Church formal flag or banner with } \\
\text { ornaments' }\end{array}$ & Tur. bayrak 'flag' (TH/HTR, 482) \\
\hline begenàti & $\begin{array}{l}\text { 'to agree with someone without } \\
\text { reservations' }\end{array}$ & $\begin{array}{l}\text { Tur. beğendi 'to approve, to be in } \\
\text { accordance with' (TH/HTR, 30) }\end{array}$ \\
\hline èvala & Yay (exclamation of approval) & $\begin{array}{l}\text { Tur. ejvallah 'goodbye, bye; thank you; it } \\
\text { is so!; let it be so; well done!' }\end{array}$ \\
\hline beričetan & 'fertile, fruitful' & $\begin{array}{l}\text { Tur. bereket 'blessing, progress, } \\
\text { fortune' (TH/HTR, 32) }\end{array}$ \\
\hline dernečiti se & 'to have fun' & $\begin{array}{l}\text { Tur. dernek (-ği) 'society, } \\
\text { companionship, association' (TH/HTR, } \\
51)\end{array}$ \\
\hline düšmanin & 'sworn enemy, foe' & Tur. düşman 'enemy’ (TH/HTR, 57 ) \\
\hline čitába & $\begin{array}{l}\text { 'an important letter or document, } \\
\text { judicial summons' }\end{array}$ & $\begin{array}{l}\text { Tur. kitab, kitap 'book; law' (TH/ } \\
\text { HTR,108) }\end{array}$ \\
\hline divániti & 'to discuss thoroughly and at length' & $\begin{array}{l}\text { Tur. divan 'to talk, to speak, to } \\
\text { converse' (Škaljić 1973: 221) }\end{array}$ \\
\hline đubre & $\begin{array}{l}\text { 'manure; a malicious, corrupt } \\
\text { individual' }\end{array}$ & Tur. gübre 'manure' (TH/HTR, 266) \\
\hline jök & 'no; there is not' (negation) & $\begin{array}{l}\text { Tur. yok 'no; it isn't; there isn't' } \\
\text { (Škaljić 1973: 371) }\end{array}$ \\
\hline kalajsati & $\begin{array}{l}\text { 'plating metallic objects with tin'; } \\
\text { (used in the expression „sunce ti } \\
\text { kalajsano") }\end{array}$ & $\begin{array}{l}\text { Originally from Tur. kalay 'tin' } \\
\text { (Škaljić 1973: 386) }\end{array}$ \\
\hline kûsur & 'small change' & $\begin{array}{l}\text { Tur. kusur 'small change' } \\
\text { (Škaljić 1973: 428) }\end{array}$ \\
\hline pobáško & 'separately' & $\begin{array}{l}\text { Tur. başka 'separate, segregated' (TH/ } \\
\text { HTR, 29) }\end{array}$ \\
\hline tava & 'pan' & Tur. tava 'pan' (TH/HTR, 179) \\
\hline veresija & 'to buy or sell with payment delay' & $\begin{array}{l}\text { tur. veresiye 'on loan' } \\
\text { (Škaljić 1973: 221) }\end{array}$ \\
\hline zero & 'spark, a small quantity' & $\begin{array}{l}\text { Tur. zerre 'small part; mote'; zèra (Tur) } \\
\text { fem. (as an adverb) reg little (RHJ, 1426) }\end{array}$ \\
\hline zeman & $\begin{array}{l}\text { 'Time'; in the expression „nije pravi } \\
\text { zeman“ (it is not the right time) }\end{array}$ & tur. zeman 'time' (TH/HTR, 474) \\
\hline
\end{tabular}

${ }^{1}$ Işikera Mehmet, Tursko-hrvatski/hrvatsko-turski rječnik, (Zagreb: Dominović, 2014).

2 Abdulah Škaljić, Turcizmi u srpskohrvatskom-hrvatskosrpskom jeziku, (Sarajevo: Svjetlost, 1973), p. 265.

${ }^{3}$ This abbreviation refers to Jure Šonje, Rječnik hrvatskoga jezika, (Zagreb: Leksikografski zavod Miroslav Krleža, Školska knjiga, 2001). 
In scholarship Turkish loanwords are categorized into six groups by Abdulah Škaljićs ${ }^{33}$ and into three groups by Brozović. ${ }^{34}$ Following the latter we have assigned the collected Turkish loanwords into the second group (kusur) and third group (avlija, veresija) as they are used in everyday speech. However, we note the indisputable presence of Turkish loanwords in standard Croatian either as generally used lexemes, e.g. boja (colour) or čarapa (sock) or as words related to particular Islamic or Oriental features, e.g. džamija (mosque) or words that are used stylistically, e.g. barjak is a word for flag used in a certain context instead of the common word zastava. ${ }^{35}$

Particular lexemes also appear as part of everyday phrases in which the Turkish loanword is essential: begenäti, in the phrase "ne begeniva mu", meaning 'does not approve someone's action'; èvala, in the phrase "evala ti", meaning 'well done, bravo'; đubre, in the phrase "đubre jedno", meaning 'scum, worthless person'; kalajsati, "sunce ti kalajsano", which is a sort of swear word; zeman, in the phrase "nije zeman od tog", meaning 'it is not yet the right time for a seasonal fruit or vegetable'.

\footnotetext{
33 The first group consists of words for which no adequate replacement can be found in Croatian, Bosnian or Serbian, e.g.: bakar, noja, bubreg, čekić, čelik, čizma, duhan, džep, don, jorgovan, kalup, katran, etc. Here we also find names of dishes (pita, baklava, burek), drink (kava), fruit $(d u d)$, clothes and clothing items (dimije, nanule), kitchen utensils (džezva, tepsija), musical instrument (tambura) and specific names for horses and horse equipment, weapons, and antiquated terms used in specific professions, trade and commerce. The second group is comprised of words for which adequate replacements can be found but are not generally used: alat, barut, bašta, čoban, ergela, jastuk, juriš, kajmak, kavez, kusur, marama, miraz, para, sandale, sanduk, šegrt, torba. In the second group Škaljić also includes words commonly used in the vernacular and sometimes used in the standard. For examples they are: barjak, bunar, čorav, dubre, hajduk, kapija, kopča. The third group consists of words that are very frequently used in everyday speech but used in the standard only when the speaker wants to emphasize a particular aspect, such as in the context of depicting past events or to create irony. These are: avlija, dušman, kubura, sokak, hajvan, nišan, ortak, pendžer, inat, veresija, dućan, hamajlija. However, Škaljić adds a fourth group in which he places words used only in certain regions and dialects, a fifth group in which he includes Turkish loanwords used in national epic, and a sixth group of Turkish loanwords that pertain to the religious terminology of Islam, Muslim life and customs. The last group also includes Muslim proper names (Škaljić Abdulah, Turcizmi u srpskohrvatskom-hrvatskosrpskom jeziku, (Sarajevo: Svjetlost, 1973), p. 15).

34 Dalibor Brozović categorizes Turkish loanwords in three groups. The first consist of generally accepted terms in the language for which no adequate replacement can be found, e.g. bakar, boja, čarapa, sat, šećer, top. The second group includes Turkish loanwords that denote all sorts of Oriental or Muslim terms such as ajet (a sentence in the Quran), Bajram, baklava, džamija, sevdalinka and many others. The third group is the largest and comprises words not used in everyday speech; stylistically neutral native words are used instead but the speaker can find Turkish loanwords which are their synonyms. For example many Croatian writers used words such as barjak or sevdah for emphasis or because they were convenient for the purpose of rhyme (D. Brozović, http://www.matica.hr/vijenac/173/Odo\%C5\%A1e\%20Turci,\%20osta\%C5\%A1e\%20 turcizmi/) accessed March 22, 2019.

35 Lisac, Osnovne štokavske značajke i hrvatski standardni jezik, p. 89.
} 
Other than Turkish loanwords predominately found in Shtokavian, our research has also recorded a great number of Romance words used by speakers of the Chakavian dialect. The term Romance loanword refers to a single word or a whole construction that belongs to a Romance language, dialect or speech and found its way into a non-Romance language. Contact between Slavonic and Romance populations caused the influx of Romance words on the territory of Eastern Adriatic. Romance loanwords are therefore "a collective name for loanwords originating in Romance languages” (http://hrvatskijezik.eu/jezicno-posudivanje/)

The oldest Romance loanwords can be dated to the end of the $8^{\text {th }}$ and beginning of the $9^{\text {th }}$ century AD. Symbiosis between the Slavic newcomers and the native Romance population continues in the centuries that follow and Latin develops into Dalmatian Romance, a variant of vulgar Latin. This language most probably became extinct in the $12^{\text {th }}$ and $13^{\text {th }}$ centuries in most areas with the exception of Dalmatian dialect of Dubrovnik which is called Ragusan and became extinct in the $15^{\text {th }}$ century, and the dialect spoken on the island of Krk which is called Vegliot. The latter became extinct with the death of its last speaker, Antonio Udaina in 1898. „Until the affirmation of national idioms, Latin had the function of language learning and written texts ranged from legal documents to literature. But with the Venetian occupation of Istria and Dalmatia, Venetian became the dominant language of the ruling layer as well as the language of trade and navigation in the Mediterranean. " ${ }^{\text {"6 }}$

Dalmatian was under pressure from Croatian in the hinterland and Venetian spreading in the Adriatic. Thus we can distinguish three layers of Romance influence: vulgar Latin (up to the $9^{\text {th }}$ century), Dalmatian (from circa $9^{\text {th }}$ to $13^{\text {th }}$ century) and Venetian (from $13^{\text {th }}$ century onwards). ${ }^{37}$

The Zadar dialect of Dalmatian does not fit either the Ragusan or the Vegliot model of Dalmatian. It undoubtedly left traces in local Croatian speech but it has not been demonstrated that a local variant of Dalmatian and (later) Venetian Italian ever coexisted at the same time. ${ }^{38}$ As we have already pointed out "Venetian rule saw to the spread of both the urban population and the Venetian dialect which soon met competition in the form of standard Italian (i.e. standard Tuscan) language (in both written and oral communication) that eventually completely replaced the Venetian idiom in written form." ${ }^{39}$ The Austrian administration allowed the new Venetian vernacular to enter Zadar, although Venetian had been present in some form for a long time before, and

\footnotetext{
36 Sočanac, Hrvatsko-talijanski jezični dodiri, p. 103.

37 Ivna Anzulović, "Nazivlje ženske odjeće zadarskog područja u pisanim izvorima”, Zadarska smotra, 4-6 (Domaća rič), Zadar (1999): 110.

38 Brozović, “O suvremenoj zadarskoj miksoglotiji..., 51.

39 Ibid., 53.
} 
gradually developed into a local dialect of a secondary organic nature. Thus three Italian idioms were used in Zadar, different in primarily sociolinguistic terms but also in material form: the local dialect, standard Italian and the vernacular (north Italian) Venetian. ${ }^{40}$

For the following period, Marković writes: "The situation in Zadar after the Treaty of Rapallo in 1920 is well-known. The entire population of the city was forcefully Italianized and a great number of Croatian inhabitants migrated into the neighbouring cities that were not under Italian rule. From that time up until the capitulation of Italy, Italian was the only idiom one could hear in the city." ${ }^{41}$

Romance idioms existed in Dalmatian speech before Slavs came to this area and the local population spoke Romance so the Slavs encountered a Romance substrate. Here as in the rest of Dalmatia, foreign words in the vernacular (seen from the perspective of standard Croatian) are mainly of Italian origin less frequently coming from other Romance languages. But the percentage of Romance words is higher than elsewhere in proper names and especially place names. ${ }^{42}$ Lisac says that foreign words in the vernacular are mostly of Italian origin and the population diversity (with many people coming from the north of Croatia and from Bosnia) allows a good degree of tolerance towards German and Oriental loanwords. ${ }^{43}$

Klaić defines Romance loanwords as "elements of Latin (or Neo-Latin) or some other Romance language in a non-Romance language." ${ }^{44}$ In this paper the term Romance loanword includes both older elements of Romance that come from Vulgar Latin and Dalmatian Romance and more recent Romance elements that include lexemes originating in the Venetian dialect, the dialect of Trieste and standard Italian. ${ }^{45}$

According to Matasović (2008), most of the Romanesque in Croatian comes from Venetian, because, as previously mentioned, Venice ruled much of our coast until the end of the 18th century. Therefore, our standard language included Venetian words, such as rúža (rose), brïga (concern), kùverta (envelope), mòrnār (sailor). ${ }^{46}$

\footnotetext{
$40 \quad$ Ibid., 55.

41 Marković “Jezični utjecaji i promjene u suvremenom govoru”, 318.

42 Brozović, “O suvremenoj zadarskoj miksoglotiji..., 61.

43 Lisac, Hrvatski govori, filolozi, pisci, p. 77.

${ }_{44}$ Bratoljub Klaić, Veliki rječnik stranih riječi, (Zagreb, Zora, 1968), p. 1151.

45 Ibid., p. 1151.

46 Matasović, Poredbenopovijesna gramatika hrvatskoga jezika, p. 311.
} 
Table 2. Romance loanwords

\begin{tabular}{|c|c|c|}
\hline WORD & $\begin{array}{l}\text { MEANING IN ZADAR } \\
\text { SPEECH }\end{array}$ & MEANING IN ITALIAN \\
\hline bićerîn & 'shot glass' & Ital. bicchierino [bikje] čašica (THR, 118) \\
\hline bôrša & 'bag' & Ital. borsa; f, wallet (THR, 120) \\
\hline bocûn & 'a big glass bottle of wine' & $\begin{array}{l}\text { Ital. Bocòn, s.m. Boccone, Tanta quantità di } \\
\text { cibo sodo quanta in una volta si mette in bocca. } \\
\text { (Boerio 1829: } 58 \text { ) } \\
\text { Ital. bottiglia [ilja] f glass bottle (THR, 2002: 129); } \\
\text { Dal. Venet. boozon, boza 'unit of liquid' + Ital. } \\
\text { augment. suffix -one. (ERHJSJ, 1, 177) }\end{array}$ \\
\hline bokâl & 'jug, most often of wine' & $\begin{array}{l}\text { Ital. boccale jug, cup (THR, 124), Tr. bocal bucal, } \\
\text { Venet. bocal (DE, I, 50) }\end{array}$ \\
\hline ćakulôn & $\begin{array}{l}\text { 'a person who talks a lot, } \\
\text { mainly untruthful things' }\end{array}$ & $\begin{array}{l}\text { Ital, chicolèta, Che ha una buona parlantina. } \\
\text { (Boerio 1829: 125) }\end{array}$ \\
\hline ćîkara & 'cup' & $\begin{array}{l}\text { chicchera f cup (THR, 124); d. Venet. cicara, Tr. } \\
\text { cicara, cichera etc. (ERHJSJ, I, 226) }\end{array}$ \\
\hline đilët & 'waistcoat, bodice' & Ital. gilè; bodice (THR, 416), \\
\hline damìžana & $\begin{array}{l}\text { 'glass bottle of wine, } \\
\text { decorated with wooden } \\
\text { trellis' }\end{array}$ & $\begin{array}{l}\text { Ital. damigiana (THR, 265), [-džana] f big } \\
\text { wicker bottle d. Venet. dameana, damiana, } \\
\text { Venet. damegiana 'etc.'; one suspects a folk } \\
\text { etymology fr. dame Janne 'lady Joanne' or the } \\
\text { Latin suffix -anus with dimidius Fr. demi, Prov. } \\
\text { Demig 'half', or even the name of a Persian city } \\
\text { Damgan, which gave Arabic damagan 'earthen } \\
\text { dishware' /damjana (Rb), dumijana (Om) } \\
\text { (ERHSJ, I, 378; Z, } 499\end{array}$ \\
\hline döta & ‘dowry’ & Ital. dote; f, dowry (THR, 314), \\
\hline facólić & 'tissue, napkin' & Ital. fazzoletto; m napkin (THR, 358), \\
\hline fâlda & 'fold on a clothing item' & Ital. falda; f rail; line (THR, 353) \\
\hline fíbra & 'fever' & $\begin{array}{l}\text { Ital. febre. 2) I'erpete che si forma sulle labbra . } \\
\text { // Attestato anche a Zara. (Doria 1991, 227) }\end{array}$ \\
\hline frìgati & 'fry in a pan' & Ital. friggere to fry $(\mathrm{HTR}, 191)$ (Doria 1991, 249) \\
\hline frïtula & 'fritter' & $\begin{array}{l}\text { Ital. Fritola. sf. fritella (Doria 1991, 249) } \\
\text { Ital. fritettella, fritter (HTR, 191) }\end{array}$ \\
\hline fûdra & 'seat padding, lining' & Ital. fodera; f padding (THR, 380), \\
\hline gîrica & 'picarel, sort of fish' & $\begin{array}{l}\text { Ital. zool. dim. di gira (picarel) pesciolino (HTR, } \\
\text { 199) }\end{array}$ \\
\hline gràdele & 'grills for roasting' & Ital. grädēlā, (grills), (HTR, 215) \\
\hline $\begin{array}{l}\text { jakèta; } \\
\text { đakavento }\end{array}$ & 'jacket' & $\begin{array}{l}\text { Ital. giacca [džàka] coat m, jacket; a vento wind } \\
\text { jacket (THR, 414), }\end{array}$ \\
\hline kàba & $\begin{array}{l}\text { 'plastic or tin basket used } \\
\text { in washing', }\end{array}$ & $\begin{array}{l}\text { Dalm. Rom. copella } \mathbf{<} \text { Vul. Lat. cupELLus (Skok } \\
\text { II, 8); noun. N. sing; coppella (crogiolo poroso) } \\
\text { melting pot } \mathrm{m}\end{array}$ \\
\hline katrîga & 'seat, chair' & $\begin{array}{l}\text { Ital. Carega. Anche cadrega (Doria 1991, 131) } \\
\text { Venet., d. Venet. carega Tr. cadrega, carega } \\
\text { (ERHJSJ, II, 63) }\end{array}$ \\
\hline
\end{tabular}


S. VRSALJKO: Some Examples of Croatian Dialects' Influence on the Lexical Diversity of the Contemporary ...

\begin{tabular}{|c|c|c|}
\hline kanatjêra & 'undershirt' & $\begin{array}{l}\text { Ital. canottiera [-jèra] (maglietta) rowing shirt } \\
\text { (THR, 154), }\end{array}$ \\
\hline kàpa & 'hat, cap' & $\begin{array}{l}\text { Ital. cappa; f cape; capello m hat, cap (THR, } \\
\text { 159), }\end{array}$ \\
\hline kàpot & 'coat' & $\begin{array}{l}\text { Ital. capoto sm. Cappoto Locc. Avv.de capoto, } \\
\text { imediamente, subito. (Doria 1991, 128) } \\
\text { Ital. cappotto [-òto] cape, raincoat (THR, 159), }\end{array}$ \\
\hline kolèt & ‘collar’ & Ital. coleto sm. colletto; (Doria 1991, 165) \\
\hline kogûma & 'coffee kettle' & $\begin{array}{l}\text { Ital. cuccuma f (bricco) kettle (THR, 259); Dal. } \\
\text { Venet., Venet., Tr. cogoma (Lat. Cuvuma) of } \\
\text { Mediterranean origin, widespread in Veneto. } \\
\text { (ERHJSJ, 1, 120) }\end{array}$ \\
\hline kredènca & $\begin{array}{l}\text { 'kitchen cupboard, dish } \\
\text { cupboard' }\end{array}$ & $\begin{array}{l}\text { Ital. credenza (armadio) kredenc m, } \\
\text { cutlery;(THR, 253); from Ital., Venet. credenza } \\
\text { ( } \leftarrow \text { Latin credentia, from credere 'to believe'; } \\
\text { the modern meaning first attested in the 14th } \\
\text { century (ERHJSJ, II, 188) }\end{array}$ \\
\hline $\begin{array}{l}\text { kròžet i } \\
\text { krožët }\end{array}$ & 'waistcoat' & $\begin{array}{l}\text { Ital. corsetto; m waist; lower waistcoat (THR, } \\
\text { 243), }\end{array}$ \\
\hline kùžina & ‘kitchen’ & Ital. cucina, kitchen (HTR, 351) \\
\hline kvàrat & 'quarter' & $\begin{array}{l}\text { Ital. un quarto; 1.adj. fourth. 2. m. quarter } f \text {. } \\
\text { quarter (THR, 771), }\end{array}$ \\
\hline làštik, & 'elastic tape' & Ital. elastico; 1. adj. elastic (THR, 324), \\
\hline mántil & 'overcoat' & Ital. mantello; m overcoat, cape (THR, 576), \\
\hline maštël & ‘open vessel of wine must’ & Ital. mastello m, vessel, basket (THR, 583), \\
\hline mudânte & 'underpants' & Ital. mutande; $f$ pl. underpants (THR, 621) \\
\hline očále, & 'glasses' & Ital. occhiali [okjàle] - pl. glasses (THR, 646), \\
\hline pêrla & 'pearl' & Ital. perla pearl m (THR, 712), \\
\hline pijàt & 'plate' & $\begin{array}{l}\text { m. plate; Ital. piatto, Venet., Tr. piato 'plate', Vegl. } \\
\text { piat. Dal. Rom. lexical item from Vul. Lat. plattus } \\
\text { from Greek platys 'wide, flat' of Indo-European } \\
\text { origin. (dem. pijätić) (DE, 315; ERHSJ, II, 677) }\end{array}$ \\
\hline pošâda & 'cuttlery, knife' & $\begin{array}{l}\text { Ital. posada sf. - posata (Doria 1991, 488) } \\
\text { Ital. posata (from posare), Venet. possada, Tr., } \\
\text { Dal. Venet. posada 'knife'. Ital. posata probably } \\
\text { from Spanish posada 'astuccio, futrola' crossed } \\
\text { with Ital. posare 'to place' (DE, 325). }\end{array}$ \\
\hline $\begin{array}{l}\text { ređìpet i } \\
\text { ređipèt }\end{array}$ & 'brassiere' & $\begin{array}{l}\text { Ital. reggippeto; m inv. brassiere'; reggineso m } \\
\text { brassiere' (THR, 791), }\end{array}$ \\
\hline $\begin{array}{l}\text { rècćina i } \\
\text { rećîna }\end{array}$ & 'earring' & Venet. rechìn s.m. (ERHSJ II, 565); noun. N. sg. \\
\hline $\begin{array}{l}\text { škafetîn i } \\
\text { škàfetin }\end{array}$ & 'drawer' & $\begin{array}{l}\text { Ital. box, chest; drawer (THR, 169); Dal. Venet.. } \\
\text { scafetin 'id', Tr. scafeto. With double diminutive } \\
\text { ending -etto and -ino from scaff a (Lucca) } \\
\text { 'wardrobe shelf' scaff a ( } \leftarrow \text { Langob. scafa)./ } \\
\text { škafet_n (Om, S) (DE, 375; ERHSJ, III, 397) }\end{array}$ \\
\hline šìgurèca & 'safety pin' & Ital. spillo di sicurezza safety pin (THR, 950), \\
\hline špalîna & 'shoulder strap' & Ital. spallina; f voj. Shoulder strap (THR, 941) \\
\hline
\end{tabular}




\begin{tabular}{|l|l|l|}
\hline štràca & 'rag' & Ital. straccio [-àčo] 1. M (pl.-cci) rag (THR, 969) \\
\hline štikadênt & 'toothpick' & $\begin{array}{l}\text { Ital. stuzzicadenti m. inv. toothpick, (THR, 975); } \\
\text { Dalm. Venet., Tr. stecadente, Venet. stecadenti } \\
\text { 'id'. Ital. stuzzicadenti is a compound from Ital. } \\
\text { stuzzicare 'to pick one's teeth' (DE, 121, 416) }\end{array}$ \\
\hline tèrina & $\begin{array}{l}\text { 'oil bowl for salad or other } \\
\text { dishes' }\end{array}$ & $\begin{array}{l}\text { Ital. terrina 'porcelain bowl for salad or other dish' } \\
\text { (Fr. terrine 'earthen bowl - terre (earth)'), Venet., } \\
\text { Tr. Terina 'soup bowl', Dal. Venet. terina 'soup or } \\
\text { salad bowl' (substantivized adjective ending in - } \\
\text { inus from terra) / ter_na (Č, Om, G), ter_na 'tray' } \\
\text { (C) (ERHSJ, III, 461; DE, 428) }\end{array}$ \\
\hline takujîn & 'wallet' & $\begin{array}{l}\text { Ital. taccuino [-ìno] m notebook, pocketbook } \\
\text { (THR, 986). In Croatian it signifies a wallet in } \\
\text { which one keeps money. }\end{array}$ \\
\hline valîža & 'travel bag, luggage' & $\begin{array}{l}\text { Ital. valigia [idža] f (pl. -gie) suitcase m; bag (THR, } \\
\text { 1043). In Croatian it denotes a heavy, full bag. }\end{array}$ \\
\hline vèšta & 'dress' & \begin{tabular}{l} 
Ital. veste; dress, clothes (THR, 1055), \\
\hline
\end{tabular}
\end{tabular}

${ }_{1}$ The abbreviation refers to Mirko Deanović, Josip Jernej, Talijansko-hrvatski rječnik (Zagreb, Školska knjiga, 2002).

${ }^{2}$ Giuseppe Boerio, Dizionario del dialetto Veneziano (Venice: Coi tipi di Andrea Santini e figlio, 1829).

${ }^{3}$ Refers to the Dalmatian Venetian dialect.

4 The abbreviation refers to Petar Skok, Etimologijski rječnik hrvatskoga ili srpskog jezika, (1-4) (Zagreb: JAZU, 1971-1974).

5 The abbreviation refers to the dialect of Trieste.

${ }^{6}$ Giacomo Devoto, Avviamento alla etimologia italiana (Dizionario etimologico) (Florence: Felice Le Monnier, 1968).

${ }^{7}$ Mario Doria, Grande dizionario del dialetto triestino (Trieste: Edizione „Trieste oggi“, 1991).

8 The abbreviation refers to Mirko Deanović, Josip Jernej, Hrvatsko-talijanski rječnik (Zagreb, Školska knjiga, 1994).

As we can see in table 2 Zadar speech still has many expression that originate in Dalmatian Venetian, e.g.: bocûn (confirmed in the dictionary G. Boerio Dizionario del Dialeletto Veneziano), cîkara, damižana, katrîga, kogûma and some expressions that come from the dialect of Trieste, e.g. bokâl. and fíbra, kolët (lexemes whose confirmation we find in Grande Dizionariu del Dialetto Triestino Maria Dorie).

The Venetian speech of Zadar differs from the Venetian vernacular. The former developed as a form of local speech or dialect (an organic idiom) of Venetian and took hold in Zadar during the period of Venetian rule while the latter spread during the period of Austrian rule in the $19^{\text {th }}$ century. The Zadar form of Venetian was mainly spoken in Arbanasi, a Zadar neighbourhood that was settled by Albanian inhabitants in the $18^{\text {th }}$ century. ${ }^{47}$ Some Venetian words continue to be used in everyday speech and are hence the primary focus of this study.

$\overline{47}$ Lisac, Hrvatski govori, filolozi, pisci, p. 75. 
Anzulović also mentions some of the words and expressions we list in the table. For example, in her research on female clothes in the Zadar area she finds the word dota (dowry), attested in written sources as early as the $12^{\text {th }}$ and $13^{\text {th }}$ century. The author analyses material pertaining to female vestments from the Middle Ages to the $20^{\text {th }}$ century. ${ }^{48}$

As we can see from tables 1 and 2 the number of Romance loanwords is significantly higher than the number of Turkish loanwords, which confirms our hypothesis that Romance loanwords are most frequent in the Chakavian dialect on the east coast of the Adriatic, and that they appear in Zadar speech, and sometimes even in standard Croatian.

\section{Conclusion}

This paper analyses traces of the influence of dialects on the lexical diversity of Zadar speech, as specified in the title. The aim of the paper was to present some examples of the lexical diversity of Zadar speech that stems from the historical influence of dialects which left traces in the speech of elderly non-native speakers in Zadar. The corpus was collected by means of informal conversations and hence the collected lexemes primarily belong to the domestic sphere and are used in everyday language. Hence, among Romance loanwords, we find many domestic terms (bićerîn, kogûma, pošâda, etc.) and clothing items (mudânte, ređipet and ređipët, kròžet and krožět, etc.).

Great population migrations and wars significantly affected the area of Zadar and its surroundings and led to the coexistence of two dialects, Chakavian and Neo-Shtokavian. Hence the paper also discussed the frequency of Turkish loanwords in the Shtokavian dialect and the frequency of Romance loanwords in the Chakavian dialect, although the two are often interwoven. The historical circumstances that affected the two dialects resulted in our choice of elderly speakers, an equal portion of whom speak either dialect. Shtokavian influence imported a smaller number of Turkish loanwords in Zadar speech because the Turkish loanwords used also became part of standard Croatian. On the other hand, Chakavian influence imported a greater number of Romance loanwords, only few of which became a part of standard Croatian.

The number of collected lexemes is certainly a result of the age of the interviewees as prior research shows the elderly use loanwords more than their junior counterparts. Further research would need to explore the presence of loanwords among the junior population which may prove valuable in ascertaining more recent influence on Zadar speech.

$\overline{48}$ Anzulović, “Nazivlje ženske odjeće zadarskog područja u pisanim izvorima”, 109. 


\section{Einige Beispiele des Einflusses kroatischer Dialekte auf die lexikalische Vielfalt des zeitgenössischen Idioms in Zadar bei nicht einheimischen Eltern}

\section{Zusammenfassung}

Die synchronische Sprachsituation des städtischen Idioms in Zadar ist das Ergebnis einer Reihe von dialektalen Einflüssen: der neo-štokawische Dialekt, der im Hinterland gesprochen wird, das čakawisch-ikawische Idiom, das in der Küstenregion Kroatiens gesprochen wird, das mittelčakawische ikawisch-ekawische Idiom und die kroatische Standardsprache. Der Sprachforscher Lisac hat festgestellt, dass das zeitgenössische Idiom der Stadt Zadar eine Mischung zweier kroatischer Dialekte, nämlich des čakawischen und des štokavischen, sei. Der čakawische Dialekt sei darüberhinaus in den mittel- und südčakawischen und der štokawische in den bosnisch-herzegowinischen und ost-herzegowinischen einzuteilen.

Infolge unterschiedlicher historischer Umstände haben sich zahlreich Lehnwörter in diese Dialekte eingeschlichen. Im štokawischen Dialekt handelt es sich zumeist um türkische und im čakawischen um romanische Lehnwörter. Diese Arbeit verwendet die Theorie von Sprachkontakten, die man auf die Forschung von Dialekten anwendet und die den Einfluss nur in jeweils einer Richtung untersucht: das Vorhandensein türkischer Lehnwörter (in seiner štokawischen dialektalen Komponente) und romanischer Lehnwörter (in seiner čakawischen Komponente) im Idiom der Stadt Zadar, aber nicht den Einfluss der kroatischen auf die türkische oder romanische Sprache. Daher ist das Kroatische die Empfangssprache (hier konkret das Idiom in Zadar) und die Gebersprachen sind jeweils das Türkische und das Romanische, zumeist das venezianische Italienisch bzw. die italienische Standardsprache. In einigen Fällen werden die sprachlichen Überreste der romanischen dalmatischen Sprache im Kroatischen untersucht. Zur Analyse wurden türkische Lehnwörter im štokawischen Dialekt und romanische Lehnwörter im čakawischen Dialekt (innerhalb des Zadarer Idioms) ausgewählt. Sie sind die häufigsten Lehnwörter dieses Idioms. Dies bezieht sich insbesondere auf die romanischen Elemente, die die kroatischen Dialekte der Küstenregion durchdringen. (Sie bleiben oft auf regionaler Ebene, aber einige sind aus dem Čakawischen in die kroatische Standardsprache übergegangen.) 
S. VRSALJKO: Some Examples of Croatian Dialects' Influence on the Lexical Diversity of the Contemporary ...

\section{Bibliography}

Anić, Vladimir et al. Hrvatski enciklopedijski rječnik, I-XII. Zagreb: Novi Liber, 2004.

Anzulović, Ivna. "Nazivlje ženske odjeće zadarskog područja u pisanim izvorima”, Zadarska smotra 4-6 (Domaća rič) (1999).

Begonja, Zlatko. "Zadar u sporazumima tijekom prve polovice XX. stoljeća (1915.-1947.)”. Radovi Zavoda za povijesne znanosti HAZU u Zadru. 49 (2007).

Boerio, Giuseppe. Dizionario del dialetto Veneziano. Venice: Coi tipi di Andrea Santini e figlio, 1829.

Brozović, Dalibor. “Sastav i osobine razgovornoga jezika”. Telegram, 2 June 1967.

Brozović, Dalibor. “Razgovorni jezik”. Telegram, 26 May 1967.

Brozović, Dalibor. "O suvremenoj zadarskoj miksoglotiji i o njezinim društveno-povijesnim i lingvističkim pretpostavkama”, Radovi Filozofskog fakulteta u Zadru 14/15. (1975-76): 49-63.

Brozović, Dalibor. Odoše Turci, ostaše turcizmi.

http://www.matica.hr/vijenac/173/Odo\%C5\%A1e\%20Turci,\%20osta\%C5\%A1e\%20turcizmi/ (Accessed on June 1,2016).

Deanović, Mirko; Jernej, Josip. Hrvatsko-talijanski rječnik. Zagreb: Školska knjiga, 1994.

Deanović, Mirko; Jernej, Josip. Talijansko-hrvatski rječnik. Zagreb: Školska knjiga, 2002.

Devoto, Giacomo. Avviamento alla etimologia italiana (Dizionario etimologico). Florence: Felice Le Monnier, 1968.

Doria, Mario. Grande dizinorio del dialetto triestino. Trieste: Edizione „Trieste oggi“, 1991.

Hraste, Mate. O govoru Zadra i okolice. Zagreb: Nakladni zavod Matice hrvatske, 1964.

Hrvatski jezik - Jezično posuđivanje. Accessed on April 2, 2019 http://hrvatskijezik.eu/jezicno-posudivanje.

Işikera, Mehmet. Tursko-hrvatski/hrvatsko-turski rječnik. Zagreb: Dominović, 2014.

Jozić, Željko. Svaka druga hrvatska riječ - nije hrvatska. Accessed on September 11, 2016, http://www.vecernji.hr/hrvatska/svaka-druga-hrvatska-rijec-nije-hrvatska-1080181

Juraga, Edo. “Turcizmi u murterskom govoru”, Čakavska rič (2010), no. 1-2: $333-342$.

Klaić, Bratoljub. Veliki rječnik stranih riječi. Zagreb: Zora, 1968.

Katičić, Radoslav. Litterarum studia - Književnost i naobrazba ranog hrvatskog srednjovjekovlja. Zagreb: Theoria, 1998. 
Lisac, Josip. "Leksičke značajke čakavskih dijalekata”, Čakavska rič (1991), no. 2: 5-20.

Lisac, Josip. “Dijalekti zadarskoga kraja”, Marulić. 3 (1996): 521-526.

Lisac, Josip. Hrvatski govori, filolozi, pisci. Zagreb: Nakladni zavod Matice hrvatske, 1999.

Lisac, Josip. "Osnovne štokavske značajke i hrvatski standardni jezik", Republika (LIX), (2003): 86 - 90.

Lisac Josip. Hrvatska dijalektologija 2. Zagreb: Golden marketing - Tehnička knjiga, 2009.

Marković, Irena. "Jezični utjecaji i promjene u suvremenom govoru Zadra”, Croatica et Slavica Iadertina. (2012): 313 - 335.

Matasović, Ranko. Poredbenopovijesna gramatika hrvatskoga jezika. Zagreb: Matica hrvatska, 2008.

Pavličević-Franić, Dunja. Komunikacijom do gramatike. Zagreb: Alfa, 2005.

Pranjković, Ivo. "Hrvatski i orijentalni jezici”. In: Zbornik Zagrebačke slavističke škole 2001. Jurković M., ed. Zagreb: Filozofski fakultet. FF press. 2002., 9 -15 .

Skok, Petar. Etimologijski rječnik hrvatskoga ili srpskog jezika, (1-4), Zagreb: JAZU, 1971.-1974.

Sočanac, Lelija. Hrvatsko-talijanski jezični dodiri. Zagreb: Nakladni zavod Globus, 2004.

Spicijarić, Nina. "Romanizmi u nazivlju kuhinjskih predmeta u govoru Dubašnice na otoku Krku”. Fluminensia, 2/1 (2009): 7 - 24.

Šonje, Jure. Rječnik hrvatskoga jezika. Zagreb: Leksikografski zavod Miroslav Krleža, Školska knjiga, 2001.

Škaljić, Abdulah. Turcizmi u srpskohrvatskom-hrvatskosrpskom jeziku. Sarajevo: Svjetlost, 1973.

Vinja, Vojmir. Jadranske etimologije - jadranske dopune Skokovu etimologijskom rječniku, vol. I. Zagreb: Školska knjiga, 1998.

Vinja, Vojmir. Jadranske etimologije - jadranske dopune Skokovu etimologijskom rječniku, vol. II. Zagreb: Školska knjiga, 2003.

Vinja, Vojmir. Jadranske etimologije - jadranske dopune Skokovu etimologijskom rječniku, vol. III. Zagreb: Školska knjiga, 2004.

Vrsaljko, Slavica. “O suvremenom zadarskom govoru”. Filologija, (February 2015), no. 64: 137-145. 